\author{
DANUTA KOPEĆ ${ }^{\star}$ \\ Poznań, Polska \\ ORCID ID oooo-0002-1874-5954
}

\title{
MENTALIZACJA W EDUKACJI OSOBY Z NIEPEŁNOSPRAWNOŚCIĄ INTELEKTUALNĄ W STOPNIU GEĘBOKIM
}

Streszczenie: Pojęcie mentalizacji w obszarze naukowej refleksji pojawiło się stosunkowo niedawno. Jest ono konstruktem transdyscyplinarnym, a jego podstawową ramą interpretacyjną jest teoria przywiązania. Większość badaczy jest zadnia, że wymaga ono jednak dalszej konceptualizacji i empirycznej konkretyzacji. W artykule zostanie podjęta wstępna próba deskrypcji mentalizacji zachodzącej w relacjach pomiędzy pedagogiem specjalnym a osobą z głęboką niepełnosprawnością intelektualną w rzeczywistości edukacyjnej. Zostanie w nim przedstawiona definicja metalizacji oraz jej wymiary: mentalizacja automatyczna i kontrolowana; mentalizacja poznawcza i afektywna: mentalizacja zorientowana na self oraz zorientowana na obiekt. W artykule zostaną scharakteryzowane przedmentalizacyjne tryby doświadczania rzeczywistości oraz wymiary mentalizacji dojrzałej. Podjęte zostaną również problemy zakłóceń w przebiegu metalizacji doświadczanych przez pedagoga specjalnego w kontakcie z osobą z głęboką niepełnosprawnością intelektualną. Egzemplifikacją zakłóceń jest m.in. traktowanie osoby z głęboką niepełnosprawnością intelektualną jako „ekranu” oraz przypinanie jej „tożsamości”. W kontekście zakłóceń w przebiegu mentalizowania zostaną przedstawione konsekwencje, jakie niesie dla osoby z głęboką niepełnosprawnością intelektualną przejście pedagoga specjalnego z trybu mentalizacji dojrzałej na przedmentalizacyjne tryby doświadczania rzeczywistości. W podsumowaniu przedstawione zostaną wnioski dotyczące ważności procesu mentalizowania w przebiegu procesu edukacji osoby z niepełnosprawnością intelektualną w stopniu głębokim.

Słowa kluczowe: metalizacja, mentalizowanie, osoba z głęboką niepełnosprawnością intelektualną, przedmentalizacyjne tryby doświadczania rzeczywistości.

* Dr hab. Danuta Kopeć, Uniwersytet im. Adama Mickiewicza w Poznaniu; e-mail: dankop@ amu.edu.pl. 


\section{Wprowadzenie}

Współcześnie w pedagogice specjalnej ${ }^{1}$, zarówno w obszarze jej teorii, jak i w obszarze praktyki, można wyodrębnić dwa nurty naukowej narracji. Egzemplifikacją pierwszego jest analiza fenomenu niepełnosprawności, z perspektywy emancypacyjnej pedagogiki specjalnej, w której kluczową rolę odgrywa ujęcie kulturowo-antropologiczne oraz etnograficzne. Jej istotę oddają w pełni studia o niepełnosprawności/nad niepełnosprawnością ${ }^{2}$ (por. Davis 1995; Krause 2010; Borowska-Beszta 2016; Garland-Thomson 2017; Pamuła, Szarota, Usiekniewicz 2018, s. 4-12; Rzeźnicka-Krupa 2019). Wart zauważenia jest fakt, że w ich obrębie cały czas jeszcze otwarte pozostaje pytanie, jaka powinna być narracja o osobie z niepełnosprawnością intelektualną ${ }^{3}$ zwłaszcza tej z niepełnosprawnością intelektualną w stopniu głębokim ${ }^{4}$ (Davis 2019; por. Kopeć 2013), jaka jest (jaka powinna być?) egzemplifikacja jej emancypacji w obszarze teorii i praktyki pedagogiki specjalnej. Na drugi z wyróżnionych przeze mnie nurtów składa się transdyscyplinarny korpus wiedzy wygenerowany poprzez najnowsze badania naukowe, m.in. z zakresu neurobiologii (por. Cozolino 2004; Siegel 2009), psychologii rozwojowej (por. Kmita 2011; Dixon 2016) oraz kogniwistyki. Mam tu na uwadze te koncepcje, czy też teorie, które potwierdzają wpływ jakości relacji interpersonalnej na funkcjonowanie psychospołeczne osoby i jej dobrostan w ciągu całego jej życia. Wśród nich

1 Nurty, o których wspominam, widoczne są nie tylko w obszarze polskiej pedagogiki specjalnej, ale również międzynarodowej. Są one również zauważalne w ramach poszczególnych subdyscyplin pedagogiki specjalnej.

$2 \mathrm{~W}$ jęz. ang. dis/ability studies. Goodley w ramach studiów o niepełnosprawności wyodrębnia różne nurty (za: Rzeźnicka-Krupa 2019, s. 49). Uważam, że dla zrozumienia problemu edukacji osób z niepełnosprawnością intelektualną istotne są przede wszystkim: critical psychological disability studies, inclusive disability studies.

3 Uprawomocnione jest stwierdzenie, że w grupie osób z niepełnosprawnościami, idee emancypacyjne najpóźniej pojawiły się w grupie osób z niepełnosprawnością intelektualną (Davis 2019).

4 W tekście za obowiązującą przyjmuję definicję niepełnosprawności intelektualnej DSM-5 (Kryteria diagnostyczne z DSM-5. Desk Reference, 2016). Świadomie nie używam często pojęcia uczeń, gdyż w przypadku osoby z niepełnosprawnością intelektualną w stopniu głębokim czas pobytu w szkole trwa do 25 roku życia (Dz.U. z 2013 roku, poz. 529). Wart zauważenia jest fakt, że osoba z głęboką niepełnosprawnością intelektualną w polskim systemie edukacji nazywana jest uczestnikiem zajęć rewalidacyjno-wychowawczych, a nie uczniem. Jest to jeden z przejawów dyskryminacji osoby z głęboką niepełnosprawnością intelektualną w polskim systemie edukacji. $\mathrm{W}$ analizowaniu problemów będących przedmiotem artykułu pomijam ich analizę w kontekście osoby z lekką, umiarkowaną i znaczą niepełnosprawnością intelektualną. Powodem mojego pominięcia nie jest unieważnienie osoby z lekką, umiarkowaną i znaczną niepełnosprawnością. Od wielu lat bowiem osoba z głęboką niepełnosprawnością intelektualną stanowi rdzeń moich eksploracji badawczych i dlatego podczas omawiania problematyki mentalizacji mogę odwołać się do zgromadzonego przez siebie materiału empirycznego. 
należy przede wszystkim wymienić teorię przywiązania ${ }^{5}$ (Bowlby1969; 1973; 1980; Ainsworth 1967), teorię intersubiektywności (Threvarten 2007; Wallin 2011; Powel, Cooper, Hoffman, Marvin 2015) oraz koncepcję mentalizowania (Allen, Fonagy, Bateman 2014). Obydwa wyżej wymienione nurty, zdawałoby się tak różniące się od siebie, wzajemnie się uzupełniają. Ich dopełnianie się jest chyba najbardziej widoczne w obszarze pedagogiki osób z niepełnosprawnością intelektualną. Narracja emancypacyjna wniesiona do ontologii i epistemologii pedagogiki specjalnej przez pierwszy z nurtów, z drugiego nurtu czerpie pomysły na urzeczywistnianie pomysłów. W odniesieniu do osoby z niepełnosprawnością intelektualną w stopniu głębokim, narracja ta wymaga namysłu i refleksji, tak aby idea emancypacji nie stała się tylko słownym ozdobnikiem. Wychodząc z założenia, że relacja pełni rolę tygla rozwojowego, można uznać, że to właśnie w niej i dzięki niej będzie można wspierać emancypację osoby z niepełnosprawnością intelektualną w stopniu głębokim $^{6}$ (Wallin 2011, s. 69; Powel, Cooper, Hoffman, Marvin 2015). W odniesieniu do edukacji osoby z niepełnosprawnością intelektualną w stopniu głębokim za relację i jej przebieg zawsze jest odpowiedzialny pedagog specjalny. Klein i Kübler stawiają nawet tezę, że „drogą” do poznania osoby z niepełnosprawnością intelektualną jest zawsze sam pedagog specjalny (za: Theunissen 2003, s. 137; por Antor, Bleidick 2000). Jeżeli pedagogowi specjalnemu uda się „zobaczyć” własny sposób percepcji osoby z niepełnosprawnością intelektualną i sposób myślenia o niej i o sobie w relacji z nią, jest szansa, że nawiąże rzeczywistą, satysfakcjonującą relację z nią spełniającą warunki „tygla rozwojowego”. Procesem, który temu wglądowi w siebie przez pedagoga specjalnego sprzyja i w pewien sposób go opisuje, jest mentalizowanie $^{7}$ (por. Allen, Fonagy, Bateman 2014; Powel, Cooper, Hoffman, Marvin 2015). Dlatego też w tekście zostanie podjęta próba analizy mentalizowania w kontekście edukacji osoby z niepełnosprawnością intelektualną w stopniu głębokim.

W artykule omówię definicję mentalizacji i jej wymiary; przedstawię cechy mentalizacji dojrzałej oraz zakłócenia w mentalizacji, w przebiegu procesu edukacji, w relacji pedagog specjalny-osoba z niepełnosprawnością intelektualną w stopniu

5 Teoria przywiązania nie jest, co prawda, teoria nową, ale w znaczący sposób cały czas wpływa na psychologię rozwojową i kliniczną dziecka (Dixon 2016; Kmita 2018). Zdaniem Kmity, „teza o kluczowym znaczeniu więzi emocjonalnej dla rozwoju psychiki ludzkiej nie budzi już żadnych zastrzeżeń; wręcz przeciwnie, wciąż inspiruje do dalszych poszukiwań badawczych, a zwłaszcza w kierunku wyjaśniania odmiennych trajektorii rozwojowych w obliczu rożnych czynników ryzyka - tak biologicznych, jak i środowiskowych" (Kmita 2018, s. 73).

6 Oczywiście, relacja jest również „tyglem rozwojowym” dla osób z lekką, umiarkowaną i znaczną niepełnosprawnością intelektualną. Należy jednak pamiętać, że ze względu na różnicę w funkcjonowania tych osób, z lekką, umiarkowaną, znaczną i głęboką niepełnosprawnością intelektualną z innymi wyzwaniami przyjdzie się mierzyć pedagogowi specjalnemu pracującemu z każdą $\mathrm{z}$ tych osób.

7 W literaturze przedmiotu funkcjonują dwa terminy; forma czasownikowa - mentalizowanie, oraz forma rzeczownikowa: mentalizacja (Marszał 2015, s. 62). W tekście będę zamiennie stosowała obie formy. 
głębokim. W podsumowaniu przedstawię wnioski dotyczące ważności procesu mentalizowania w przebiegu procesu edukacji osoby z niepełnosprawnością intelektualną w stopniu głębokim.

\section{Definicja mentalizacji i jej wymiary}

Badacze zajmujący się mentalizacją są zgodni co do tego, że mentalizacja jest „stosunkowo «młodym» konstruktem, który wymaga dalszej konceptualizacji i uszczegółowienia", m.in. dlatego że jest ona konstruktem wielowymiarowym i bardzo złożonym (Cierpiałkowska, Górska 2016, s. 7; Stawicka, Górska 2016, s. 42; por. Allen, Fonagy, Bateman 2014, s. 34) ${ }^{8}$. Podstawową ramą interpretacyjną mentalizacji jest teoria przywiązania (Allen, Fonagy, Bateman 2014; Marszał 2015; Stawicka, Górska 2016). W literaturze przedmiotu występują różne ujęcia definicyjne mentalizacji (Allen, Fonagy, Bateman 2014; Stawicka, Górska 2016). Dla moich rozważań dotyczących mentalizowania w przebiegu procesu edukacji osoby z głęboką niepełnosprawnością intelektualną przyjmuję za obowiązującą definicję metalizacji zaproponowaną przez Marszał, z uwagi na jej wysoką wartość eksplanacyjną (2015). Zdaniem badaczki, mentalizacja to:

- „wyobrażeniowy proces psychiczny, polegający na odbieraniu i rozumieniu zachowań własnych i innych osób jako wynikających $\mathrm{z}$ intencjonalnych stanów emocjonalnych;

- zakłada zdolność do tworzenia reprezentacji przyczynowych stanów umysłów własnych i innych osób oraz do różnicowania między wewnętrzną i zewnętrzną rzeczywistością;

- w wyjaśnianiu zachowań zakłada uznanie okoliczności, kontekstu i przeszłych doświadczeń jednostki;

- $\quad \mathrm{w}$ większości jest procesem przebiegającym w sposób automatyczny i nieświadomy;

- oprócz oczywistych związków z funkcjonowaniem interpersonalnym, podkreśla się jej znaczenie dla procesów samoregulacji, np. jest nieodłącznie związana ze zdolnością do regulacji emocjonalnej i tworzeniem spójnego obrazu self" (2015, s. 63).

W literaturze przedmiotu wyróżnia się trzy wymiary mentalizacji. Autorami tej klasyfikacji są badacze pracujący w zespole Fonagy'ego (Marszał 2015, s. 64). Każdy z wymiarów jest związany z innym obszarem działalności mózgu. Uwzględniając poszczególne wymiary mentalizacji, w literaturze przedmiotu wyróżnia się:

8 Marszał wspomina, że pojęcie mentalizacji funkcjonuje w literaturze przedmiotu od lat 7o. XX wieku (2015, s. 61). Zdaniem badaczki, było ono stosowane w kontekście teorii umysłu. Jednak takiemu rozumieniu mentalizacji stawiano zarzut pomijania czegoś, co dla mentalizacji jest bardzo istotne, a mianowicie, relacyjnego i emocjonalnego rozumienia zachowania (Marszał 2015, s. 61). 
- mentalizację automatyczną i kontrolowaną;

- mentalizację poznawczą i afektywną;

- mentalizację zorientowaną na self i mentalizację zorientowaną na obiekt (za: Marszał 2015, s. 64).

Poniżej charakteryzuję każdy z wyróżnionych przez zespół Fonagy’ego wymiarów mentalizacji.

\section{Mentalizacja automatyczna i kontrolowana}

Cechą mentalizacji automatycznej jest to, że przebiega w sposób nieświadomy i nierefleksyjny; w trakcie jej przebiegu nie są wykorzystywane procesy związane $z$ uwagą. Co ważne, „, $[\mathrm{w}]$ trybie mentalizacji automatycznej reprezentacje stanów mentalnych powstają na podstawie wcześniejszych doświadczeń (podkreślenie aut.) i w sposób automatyczny warunkują dalszy proces przetwarzania informacji" (Marszał 2015, s. 65; Górska, Cierpiałkowska 2016). Natomiast mentalizacja kontrolowana przebiega w sposób świadomy i refleksyjny. Dla jej przebiegu istotną rolę odgrywają kompetencje werbalne osoby. Należy pamiętać, że do czynników hamujących mentalizację kontrolowaną należą m.in. wysokie pobudzenie emocjonalne oraz silny stres (Marszał 2015). Warto zauważyć, że w trakcie procesu mentalizowania mogą wystąpić oba tryby mentalizacji jednocześnie, tzn. automatyczny i kontrolowany. Istotnym czynnikiem mającym wpływ na przejście osoby z trybu mentalizacji kontrolowanej na automatyczną jest np. umiejętność regulowania przez nią emocji (podkreślenie aut.) (Marszał 2015; Stawicka, Górska 2016).

\section{Mentalizacja poznawcza i afektywna}

Mentalizację poznawczą w literaturze przedmiotu opisuje się najczęściej za pomocą „teorii umysłu” (Marszał 2015; Górska, Cierpiałkowska 2016). Zdaniem Barona-Cohena i jego zespołu, mentalizacja poznawcza to „zdolność do tworzenia reprezentacji stanów epistemicznych i myślenia w kategoriach przekonań oraz przypisywania innym osobom przekonań i pragnień w celu rozumienia i przewidywania ich zachowań społecznych" (za: Marszał 2015, s. 68). Na mentalizację poznawczą składają się takie procesy, jak: „1) rozpoznawanie i rozróżnianie własnych stanów umysłowych oraz zdolność do poddawania refleksji psychologicznych czynników warunkujących motywacje, myślenie i działanie jednostki; 2) analogiczne wnioskowanie o stanach mentalnych innych osób na podstawie obserwowanych wskaźników; 3) przewidywanie i wyjaśnianie zachowania z wyzyskaniem posiadanej wiedzy o ludzkim umyśle" (Marszał, Kamza 2016, s. 66). Dzięki mentalizacji afektywnej osoba potrafi rozpoznać stany emocjonalne, rozumie je i potrafi na ich temat wnioskować (Marszał 2015; Stawicka, Górska 2016). Badacze zwracają uwagę na to, że na mentalizację afektywną składa się również regulacja własnych emocji 
ze względu na rozumienie intencji, uczuć i przekonań9 (Marszał 2015; Górska, Cierpiałkowska 2016; Stawicka, Górska 2016).

\section{Mentalizacja zorientowana na self i mentalizacja zorientowana na obiekt}

Proces mentalizacji może przebiegać w dwóch kontekstach. Autorefleksyjnym, w którym wnioskowanie dotyczy stanów własnego umysłu, w literaturze przedmiotu mówi się wówczas o mentalizacji zorientowanej na self. Mentalizacja może przebiegać również w kontekście interpersonalnym, dotyczy ona wówczas wnioskowania o stanach mentalnych innych osób; jest to mentalizacja zorientowana na obiekt (Marszał 2015; Górska, Cierpiałkowska 2016; Stawicka, Górska 2016).

\section{Cechy dojrzałej mentalizacji}

W literaturze przedmiotu podkreśla się, że mentalizacja może być ujmowana jako cecha osoby, tj. jej indywidualny poziom zdolności do mentalizowania lub stan, tj. aktywowanie cechy w określonym kontekście sytuacyjnym (Marszał 2015; Górska, Cierpiałkowska 2016; Stawicka, Górska 2016, s. 52-53). Zespół Fonagy’ego stworzył Skalę Funkcji Refleksyjnej służącej pomiarowi mentalizacji, która uzyskała dobre wskaźniki psychometryczne (Stawicka, Górska 2016). W tej skali uwzględnione zostały cztery wymiary mentalizacji: (a) świadomość natury i stanów umysłu; (b) podejmowanie świadomego wysiłku rozpoznania stanów umysłowych leżących u podłoża obserwowanych zachowań; (c) świadomość rozwojowej natury stanów umysłu; (d) świadomość stanów umysłowych w interakcjach z innymi (Stawicka, Górska 2016) ${ }^{10}$. Mentalizacja dojrzała, czyli tryb właściwego mentalizowania, który nie wydaje się przesadnie rzeczywisty ani nierzeczywisty, uznaje je bowiem za przejaw różnych punktów widzenia rzeczywistości (Allen, Fonagy, Bateman 2014, s. 140).

Obok mentalizacji dojrzałej można wyróżnić trzy przedmentalizacyjne tryby doświadczania rzeczywistości. Są nimi:

- „tryb teleologiczny, w którym stany psychiczne, takie jak potrzeby i emocje zostają wyrażone w działaniu; w trybie teleologicznym liczą się tylko dzialania ich namacalne skutki; zachowania interpretowane są w kategoriach fizycznych działań i skutków;

- tryb «równoważności psychicznej» charakteryzuje się tym, że świat wewnętrzy i zewnętrzna rzeczywistość są tożsame; reprezentacje psychiczne

9 W literaturze przedmiotu występuje termin „mentalizowana emocjonalność”, który oznacza mentalizowanie emocji przy jednoczesnym ich doświadczaniu (Marszał 2015, s. 69; por. Górska, Cierpiałkowska 2016).

10 Opis poszczególnych wymiarów skali przedstawiony został przez Stawicką i Górską (2016, s. 52-53). 
nie są od różniane od zewnętrznej rzeczywistości, która reprezentują; stany umysłu są przeżywane jako rzeczywiste - jak w marzeniach sennych, wspomnieniach czy urojeniach;

- tryb doświadczenia «na niby», jego cechą charakterystyczną jest to, że stany psychiczne są odróżniane od świata zewnętrznego, ale wydają się nierzeczywiste $\mathrm{w}$ tym sensie, że nie są zakorzenione w rzeczywistości (lub nie mają z nią związku)" (Allen, Fonagy, Bateman 2014, s. 140; Stawicka, Górska 2016, s. 54; por. Marszał 2015).

\section{Zakłócenia mentalizowania $\mathrm{w}$ relacji z osobą z niepełnosprawnością intelektualną w stopniu głębokim - pedagog specjalny}

Zakłóceniom w mentalizacji mogącym się pojawić podczas „edukacyjnego spotkania" między osobą z niepełnosprawnością intelektualną w stopniu głębokim a pedagogiem specjalnym chciałabym się przyjrzeć w kontekście jednego z wyróżnionych $\mathrm{w}$ literaturze przedmiotu kryteriów opisu mentalizacji, a mianowicie tego, w którym jest ona rozumiana jako dynamiczny stan podlegający zmianom w zależności od kontekstu sytuacyjnego (por. Marszał 2015, s. 84). Należy pamiętać, że sytuacja, w której osoba doświadcza silnego stresu i/lub wysokiego pobudzenia emocjonalnego, może skutkować zakłóceniom w przebiegu mentalizacji dojrzałej i przejściem na przedmentalizacyjne tryby doświadczania rzeczywistości. Ich konsekwencją, w odniesieniu do edukacji osoby z niepełnosprawnością intelektualną w stopniu głębokim, jest relacja, która przestaje spełniać warunki bezpiecznej ${ }^{11}$, tym samym nie spełnia ona warunków, aby być dla osoby tyglem rozwojowym. Jest ona również niekorzystna z perspektywy rozwojowej dla pedagoga specjalnego.

Należy pamiętać, że osoba $\mathrm{z}$ niepełnosprawnością intelektualną $\mathrm{w}$ stopniu głębokim, z powodu licznie występujących uszkodzeń wielu sfer swojego funkcjonowania jest bardzo wymagającym beneficjentem edukacji i partnerem interakcji (Szychowiak 2007; Kopeć 2013). Z powodu wspomnianych uszkodzeń, które dotyczą m.in. sfer poznawczej, motorycznej, jak również analizatorów, wzrokowego, słuchowego, bardzo trudno nie tylko nawiązać relację z osobą z głęboką niepełnosprawnością intelektualną, lecz także trwać w tej relacji (por. Bernasconi, Böing 2015). Również szeroko rozumiana fizyczność osoby, cechująca się abiektalnością, nie zachęca do wejścia z nią w relację i trwania w niej (por. Fröhlich 2016). Pedagog specjalny może doświadczać na sobie samym, w swoim ciele, licznych

11 Relacja bezpieczna jest ufna. Zdaniem Bowlb'ego, ufna relacja powinna spełniać dwie funkcje: „bezpiecznej przystani: jest nią wówczas, jeżeli jest źródłem komfortu emocjonalnego i poczucia bezpieczeństwa oraz bezpiecznej bazy: jest nią wówczas, gdy jest podstawą bezpiecznej baza dla eksploracji nie tylko świata zewnętrznego, ale również świata wewnętrznego; funkcja «bezpiecznej bazy» aktywizuje eksplorację" (Powel, Cooper, Hoffman, Marvin 2015, s. 58). 
niepełnosprawności osoby ${ }^{12}$ (Zalewska 1998). Egzemplifikacją tego procesu jest następująca wypowiedź nauczyciela: „Czuję się taka zamknięta, jak jestem z nimi [tj. uczniami z głęboką niepełnosprawnością intelektualną - uwaga aut.]. W ubiegłym roku szkolnym to było psychicznie dla mnie bardzo trudne do wytrzymania, dlatego poprosiłam dyrekcję o zmianę i w tym roku nie jestem cały czas z nimi [tj. uczniami z głęboką niepełnosprawnością intelektualną - uwaga aut.], jestem też w klasach z tymi sprawniejszymi uczniami [tj. uczniami z umiarkowanym i znacznym stopniem niepełnosprawności intelektualnej - uwaga aut.] i pracuje mi się dużo lepiej"13 (Kopeć 2013, s. 303; por. Powel, Cooper, Hoffman, Marvin 2015).

Ten swoisty proces „bycia zamykanym we własnym ciele”, który jest udziałem pedagoga specjalnego, może być dla niego bardzo trudnym przeżyciem psychicznym zwiększającym poziom stresu oraz pobudzenie emocjonalne, a w konsekwencji ewokującym zakłócenia w przebiegu procesu mentalizowania (Kopeć 2013; Marszał 2015). Ich egzemplifikacją jest przejście osoby z trybu mentalizacji dojrzałej na przedmentalizacyjne tryby doświadczania siebie i innych. Mogą one przybierać rożne formy. Jedną z nich jest rzutowanie przez pedagoga specjalnego własnych stanów emocjonalnych na osobę z niepełnosprawnością intelektualną w stopniu głębokim, która staje się dla niego „ekranem”, na który projektuje wewnętrzne stany własnego umysłu (Kopeć 2013; por. Cramer 2003, s. 51-52). Inna forma może polegać na „przypinaniu tożsamości” osobie z niepełnosprawnością intelektualną w stopniu głębokim niebędącej jej własną (por. Zalewska 1998, s. 39-41; Cramer 2003, s. 13). „Przypięta tożsamość”, z perspektywy pedagoga specjalnego, ułatwia mu wyjaśnienie zachowania osoby z głęboką niepełnosprawnością intelektualną, może również podpowiadać algorytm postępowania względem niej i jej nieakceptowanych przez pedagoga specjalnego zachowań. Przypiętą tożsamością może być np. tożsamość „niegrzecznego ucznia”, „ucznia, który wymusza”, „śpiącej królewny”, „lenia”, „uparciucha”, „agresywnego ucznia” (Kopeć 2013, s. 305). Oto wypowiedzi pedagogów specjalnych, które stanowią egzemplifikację „przypiętej tożsamości: „tożsamość ucznia, który jest niegrzeczny”: «z nią to tak zawsze, bo

12 Zalewska, analizując relacje interpersonalne osoby słyszącej z dzieckiem niesłyszącym, stwierdza, że „dziecko głuche pozbawia narzędzia kontaktu słownego osobę słyszącą [...], bo są one dla niego słuchowo niedostępne. Na tym polega [...] specyfika głuchoty w relacji interpersonalnej - głuchota jako właściwość życia psychicznego głuchego człowieka pozbawia, odbiera osobie słyszącej taką właściwość jej życia psychicznego, jaką jest mówienie” (1998, s. 18). „[...] można powiedzieć, że kontakt osoby z własnym, i nie tylko własnym [przypis aut.] głuchym dzieckiem, narusza jej tożsamość" (Zalewska 1998, s. 19). Należy również zauważyć, że osoby pozostające w kontakcie z dzieckiem niewidomym mają bardzo często poczucie swoistego „poczucia unicestwienia fizycznego" - czują, że ich nie ma, że nie istnieją (Zalewska 1998, s. 85). Można przypuszczać, że taki proces może mieć miejsce również w relacji osoba z niepełnosprawnością intelektualną w stopniu głębokim - pedagog specjalny.

13 Wypowiedź pedagoga specjalnego pochodzi ze zrealizowanego projektu badawczego, którego przedmiotem była rzeczywistość edukacyjna osoby z głęboką niepełnosprawnością intelektualną; został zrealizowany w paradygmacie interpetatywnym (Kopeć 2013). 
ona jest [chodzi o osobę z głęboką niepełnosprawnością intelektualną - uwaga aut.] po prostu niegrzeczna, nic jej się nie podoba i nie bardzo chce pracować. To przecież tak nie może być, żeby dziecko dyktowało, co będzie robić»; „tożsamość ucznia, który wymusza": «wymusza [chodzi o osobę z głęboką niepełnosprawnością intelektualną - uwaga aut. ] wszystko płaczem, płacze i płacze, byle tylko dać mu spokój. I jak tu z nim pracować?!»; „tożsamość ucznia, który jest uparty”: «zawsze się upiera [chodzi o ucznia z głęboką niepełnosprawnością intelektualną - uwaga aut.], nigdy od razu nie podejmuje aktywności, która jest dla niego przygotowana. Musi powalczyć, zanim zacznie robić to, co powinien. ;,tożsamość ucznia, który zawsze jest pogodny": «On [chodzi o ucznia z głęboką niepełnosprawnością intelektualną - uwaga aut.], jest zawsze taki pogodny. Cały czas się uśmiecha. $\mathrm{Na}$ nic się nie uskarża. Nie mam z nim żadnych problemów»" (Kopeć 2013, s. 305) ${ }^{14}$.

Można zatem postawić pytanie, jakie są konsekwencje przejścia pedagoga specjalnego z trybu mentalizacji dojrzałej na przedmentalizacyjne tryby doświadczania dla osoby z głęboką niepełnosprawnością intelektualną. Najbardziej dotkliwą dla niej jest jej uprzedmiotowienie, które skutkuje unicestwianiem jej osobowego Ja. W konsekwencji nie dochodzi do rzeczywistego spotkania osoby z głęboką niepełnosprawnością intelektualną z pedagogiem specjalnym. Traktując osobę jako „ekran”, pedagog specjalny nie spotyka się z nią, tylko z sobą samym, z wyprojektowanymi aspektami swojego świata wewnętrznych przeżyć (Kopeć 2013). „Przypięta tożsamośćc staje się również przeszkodą do spotkania z osobą z głęboką niepełnosprawnością intelektualną. Uniemożliwia ona bowiem przeprowadzenie adekwatnej diagnozy funkcjonalnej osoby, a tym samym skonstruowanie odpowiedniego dla niej indywidualnego programu edukacyjno-terapeutycznego, którego celem jest wspieranie jej rozwoju i niezależności. Zarówno diagnoza funkcjonalna, jak i indywidualny program edukacyjno-terapeutyczny odnoszą się bowiem do „przypiętej tożsamości», a więc do «mentalnego konstruktu» jego twórcy - pedagoga specjalnego, odnoszą się zatem do kogoś, kto realnie nie istnieje" (Kopeć 2013, s. 306). Konsekwencje zakłóceń w przebiegu mentalizowania pedagoga specjalnego ponosi osoba z głęboką niepełnosprawnością intelektualną w każdej ze sfer swojego funkcjonowania. Staje się ona bowiem bezpośrednim adresatem skonstruowanego programu edukacyjno-terapeutycznego, który powstał w kontekście przypiętej jej przez pedagoga specjalnego tożsamości (Kopeć 2013, s. 306). Zostaje zatem zaprzepaszczona szansa na rzeczywiste wspieranie rozwoju osoby z głęboką niepełnosprawnością intelektualną.

Zasadne jest postawienie pytania o konsekwencje zakłóceń metalizacji dla pedagoga specjalnego. Bliższe poznanie ich wymaga dalszych pogłębionych badań empirycznych i studiów teoretycznych. Na ten czas uprawniona jest konstatacja,

14 Wypowiedzi pedagogów specjalnych pochodzą ze zrealizowanego projektu badawczego, którego przedmiotem była rzeczywistość edukacyjna osoby z głęboką niepełnosprawnością intelektualną, opisanego w paradygmacie interpetatywnym (Kopeć 2013). 
że w sytuacji braku reflektowania zakłóceń w mentalizowaniu pedagog specjalny będzie nie tylko „oddalał” się od osoby z niepełnosprawnością intelektualną, ale również od siebie. Proces ten m.in. może facyliotwać synodrom wypalenia zawodowego (por. Kopeć 2013; Pohl 2016).

\section{Podsumowanie}

Mentalizacja odgrywa istotną rolę w przebiegu procesu edukacji osoby z głęboką niepełnosprawnością intelektualną. Tylko pedagog specjalny, charakteryzujący się dojrzałym trybem mentalizacji, jest w stanie stworzyć takie warunki edukacyjne, aby były one w pełni satysfakcjonujące dla osoby z głęboką niepełnosprawnością intelektualną, która jest bardzo wymagającym beneficjentem edukacji (por. Powel, Cooper, Hoffman, Marvin 2015). Dojrzały tryb mentalizacji będzie umożliwiał pedagogowi specjalnemu również wgląd w siebie, co jest warunkiem sine qua non bycia $\mathrm{w}$ relacji z osobą z niepełnosprawnością intelektualną w stopniu głębokim, relacji mającej cechy „tygla rozwojowego” (Klein, Kübler, za: Theunissen 2003, s. 137; Allen, Fonagy, Bateman 2014).

Konieczna jest również dalsza konceptualizacja i uszczegółowienie konstruktu „mentalizacji” w obszarze edukacji osób z głęboką niepełnosprawnością intelektualną (por. Marszał 2015; Cierpiałkowska, Górska 2016, s. 7). Badania empiryczne dotyczące mentalizacji w edukacji osoby z głęboką niepełnosprawnością intelektualną powinny dotyczyć dwóch podmiotów wchodzących w relację podczas edukacji, a więc osoby z głęboką niepełnosprawnością intelektualną, pedagoga specjalnego oraz kontekstu, w którym procesy edukacyjne zachodzą z uwzględnieniem mikrosystemu i makrosystemu (por. Bronfenbrenner 2005; Bronfenbrenner, Moris 1998; Schalock i inni 2010). Uwzględniając perspektywę osoby z głęboką niepełnosprawnością, ważne jest, żeby zwrócić uwagę na wpływzakłóceń w przebiegu mentalizacji na poszczególne sfery jej istnienia, przede wszystkim na sferę poznawczą, społeczno-emocjonalną oraz komunikację. Mając natomiast na uwadze osobę pedagoga specjalnego, badania empiryczne powinny dotyczyć wpływu zakłóceń w przebiegu mentalizacji na samego fizjoterapeuty, z uwzględnieniem sfery osobistej (JA-OSOBA) oraz zawodowej (JA-PEDAGOG SPECJALNY) oraz na osobę z głęboką niepełnosprawnością intelektualną. Otrzymane wyniki badań będę bardzo pomocne w procesie konceptualizacji systemu wspierania pedagogów specjalnych pracujących z osobami nie tylko z głęboką niepełnosprawnością intelektualną, lecz także z lekką, umiarkowaną i znaczną. 


\section{Bibliografia}

Allen J.G., Fonagy P., Bateman A.W. (2014). Mentalizowanie w praktyce klinicznej. Cierpisz M. (tłum.). Kraków: Wydawnictwo UJ.

Ainsworth M.D.S. (1967). Infancy in Uganda. Infant care and the growth of love. Oxford: John Hopikns Press.

Antor G., Bleidick U. (200o). Behindertenpädagogik als angewandte Ethik. Stuttgart: BerlinKöln: Verlag W. Kohlhammer.

Bernasconi T., Böing U. (2015). Pädagogik bei schwerer und mehrfacher Behinderung. Stuttgart: Kohlhammer.

Borowska-Beszta B. (2016). Wkład antropologii kulturowej $w$ studia nad niepetnosprawnościq̨. „Interdyscyplinarne Konteksty Pedagogiki Specjalnej”, nr 15, s. 15-41.

Bowlby J.(1969). Attachment and loss, vol. 1: Attachment. New York: Penguin Books.

Bowlby J. (1973). Attachment and loss, vol. 2: Separation. New York: Penguin Books.

Bowlby J. (1980). Attachment and loss, vol. 2: Loss: Sadness and depression. New York: Penguin Books.

Bronfenbrenner,U. (2005). The bioecological theory of human development. W: Bronfenbrenner U. (red.). Making human beings human: Bioecological perspectives on human development. Thousand Oaks, CA: Sage Publications, s. 3-15.Bronfenbrenner U., Morris P.A.(1998). The ecology of developmental Processes, W: Damon W. (series ed.), Lerner R.M. (Vol. Ed.). Handbook of child psychology, vol. 1: Theoretical models of human development (5th ed.). New York: John Wiley, s. 993-1028.

Cierpiałkowska L., Górska D. ( 2016). Wprowadzenie. W: Cierpiałkowska L., Górska D. (red.). Mentalizacja z perspektywy rozwojowej i klinicznej. Poznań: Wydawnictwo UAM, s. 7-10.

Cozolino L.J. (2004). Neuronauka w psychoterapii. Budowa i przebudowa ludzkiego mózgu, tłum. Gilewicz J. Poznań: Wydawnictwo Zysk i S-ka.

Cramer B. (2003). Pierwsze dwa lata. Co dzieje się pomiędzy matką, ojcem a dzieckiem?. Modzelewska E. (tłum.). Gdańsk: GWP.

Davis L. (1995). Enforcing Normalcy: Disability, Deafness, and the Body. London: Verso.

Dixon W. (2016). Twenty studies that revolutionized child psychology, wyd. 2. New York: Saddle River.

Fröhlich A.D. (2016). Na początek: pedagogika - w petni bazalnie, W: Fröhlich A.D. (red.). Edukacja bazalna. Nauczanie i terapia dzieci z glęboka niepetnosprawnością intelektualna, tłum. Namińska R. Sopot: GWP, s. 13-16.

Garland-Thomson R. (2017). Niezwykłe ciała. przedstawienia niepelnosprawności fizycznej $w$ amerykańskiej kulturze i literaturze, tłum. Pamuła N.. Warszawa: Teatr 21.

DSM-5 (Kryteria diagnostyczne z DSM-5. Desk Reference). (2016). Wrocław: Erda Urban \& Partner.

Davis L. (2019). Głos $w$ dyskusji podczas III seminarium poświęconego studiom o niepełnosprawności na Wydziale Studiów Edukacyjnych UAM, pt. Disability and Poverty, 15 listopada 2019 roku. 
Górska D., Cierpiałkowska L. (2016). Mentalizacja jako stan i jako cecha - perspektywa procesualna. Cierpiałkowska W.L., Górska D. (red.). Mentalizacja z perspektywy rozwojowej i klinicznej. Poznań: Wydawnictwo UAM, s. 13-41.

Kmita G. (2018). Co analiza $w$ triadzie matka-ojciec-dziecko wnosi do rozumienia problemów dzieci zagrożonych zaburzeniami rozwoju i ich rodziców. W: Święcicka W.M. (red.). W relacji. Studia z psychologii klinicznej dziecka 30 lat później. Warszawa: Wydawnictwo Paradygma, s. 69-88.

Kmita G. (2011). Psychoterapia i niemowlęta. W: Grzesiuk L., Suszek H. (red.). Psychoterapia. problemy pacjentów. Warszawa: Wydawnictwo Eneteia, s. 399-340.

Kopeć D. (2013). Rzeczywistość (nie) edukacyjna osoby z głęboką niepełnosprawnościa intelektualna. Zbiorowe instrumentalne studium przypadku. Poznań: Wydawnictwo Naukowe UAM.

Krause A. (2010). Współczesne paradygmaty pedagogiki specjalnej. Kraków: Impuls.

Marszał M. (2015). Mentalizacja w kontekście przywiązania. Zdolność do rozumienia siebie i innych u osób z osobowościq „borderline”. Warszawa: Difin SA.

Marszał M., Kamza A. (2016). Poznawcze źródła mentalizacji. W: Cierpiałkowska W.L., Górska D. (red.). Mentalizacja z perspektywy rozwojowej i klinicznej. Poznań: Wydawnictwo UAM, s. 65-92.

Pamuła N., Szarota M., Usiekniewicz M. (2018). „Nic o nas bez nas”. „Annales Universitatis Paedagogicae Cracoviensis. Studia de Cultura”, nr 10 (1), s. 4-12.

Pohl L. (2016). Kto tu kogo wychowuje? W: Fröhlich A.D. (red.). Edukacja bazalna. Nauczanie i terapia dzieci z głęboką niepetnosprawnościa intelektualną, Namińska R. (tłum.). Sopot: GWP, s. 137-147.

Powel B., Cooper G., Hoffman K., Marvin B. (2015). Krąg ufności. Interwencja wzmacniajaca przywiazanie we wczesnych relacjach rodzic-dziecko. Kraków: Wydawnictwo UJ.

Rzeźnicka-Krupa J. (2019). Spoleczne ontologie niepełnosprawności. Ciało, tożsamość, performatywność. Kraków: Impuls.

Schalock R.L., Borhwick-Duffy S.A., Luckasson R. i in. (2010). Intellectual Disability. Definitione, Classification and Systems of Supports. The AAIDD Ad Hoc Committee on Terminology and Classification. 11th Edition. Washington: AAIDD.

Siegel D. (2009). Rozwój umystu. Jak stajemy się tym, kim jesteśmy. Kraków: WUJ.

Stawicka M., Górska D. (2016). Mentalizacja w kontekście przywiązania. Cierpiałkowska W.L., Górska D. (red.). Mentalizacja z perspektywy rozwojowej i klinicznej. Poznań: Wydawnictwo UAM, s. 42-64.

Szychowiak B. (2007). Funkcjonowanie poznawcze osoby z głęboka niepełnosprawnościa intelektualna (niepublikowane materiały dydaktyczne opracowane do przedmiotu: psychologia osób z niepełnosprawnością intelektualną, realizowanego na kierunku pedagogika specjalna, specjalność: edukacja).

Theunissen G. (2003). Schulische Bildung von Schülerinnen und Schüler mit schwerer geistiger und mehrfacher Behinderung aus der Empowerment-Perspektive. W: Klau $\beta$ Th., Lamers W. (red.). Alle Kinder alles lehren... Grundlagen der Pädagogik für Menschen 
mit schwerer und mehrfacher Behinderung. Heidelberg: Universitätsverlag Winter GmbH, s. 129-141.

Trevarthen C. (2007). Postawy intersubiektywności: rozwój rozumienia innych ludzi i rozumienia kooperacyjnego u małych dzieci. W: Bokus B., Shugar G. (red.). Psychologia języka. Gdańsk: GWP, s. 101-123.

Wallin D.J. (2011). Przywiązanie w psychoterapii, tłum. Cierpisz M. Kraków: Wydawnictwo Uniwersytetu Jagiellońskiego.

Zalewska M. (1998). Dziecko w autoportrecie z zamalowana twarza. Warszawa: Jacek Santorski \& CO. Wydawnictwo.

\section{Akty prawne}

Rozporzadzenie Ministra Edukacji Narodowej z dnia 23 kwietnia 2013 roku w sprawie warunków i sposobu organizowania zajęć rewalidacyjno-wychowawczych dla dzieci i młodzieży z upośledzeniem umysłowym w stopniu głębokim (Dz. U. z 2013 roku, poz. 529).

\section{MENTALIZATION IN EDUCATION OF PEOPLE WITH PROFOUND INTELLECTUAL DISABILITIES}

The concept of mentalization in the field of scientific reflection has appeared relatively recently. It is a transdisciplinary construct with the theory of attachment as its basic interpretive framework. Most researchers are of the opinion that it requires further conceptualization and empirical concretization. The article is a preliminary attempt to describe mentalization occurring in the relationship between a special education teacher and a person with profound intellectual disabilities in the educational reality. The text will present the definition of mentalization and its dimensions: automatic and controlled mentalization; cognitive and affective mentalization: self-oriented and object-oriented mentalization. It will also characterize the pre-mentalization modes of experiencing reality and the dimensions of mature mentalization. The challenges of disruptions in the course of mentalization experienced by a special educator in contact with a person with profound intellectual disabilities will also be addressed. The disruptions are exemplified by, inter alia, treating a person with profound intellectual disability as a "screen" and imputing their "identity". In the context of disruptions in the course of mentalizing, the consequences of the transition of a special educator from mature mentalization to pre-mentalization modes of experiencing reality will be presented for a person with profound intellectual disabilities. The summary will present conclusions on the importance of the mentalizing process in the course of the education process of a person with profound intellectual disabilities.

Keywords: mentalization, mentalizing, people with profound intellectual disabilities, pre-mentalization modes of experiencing reality. 
